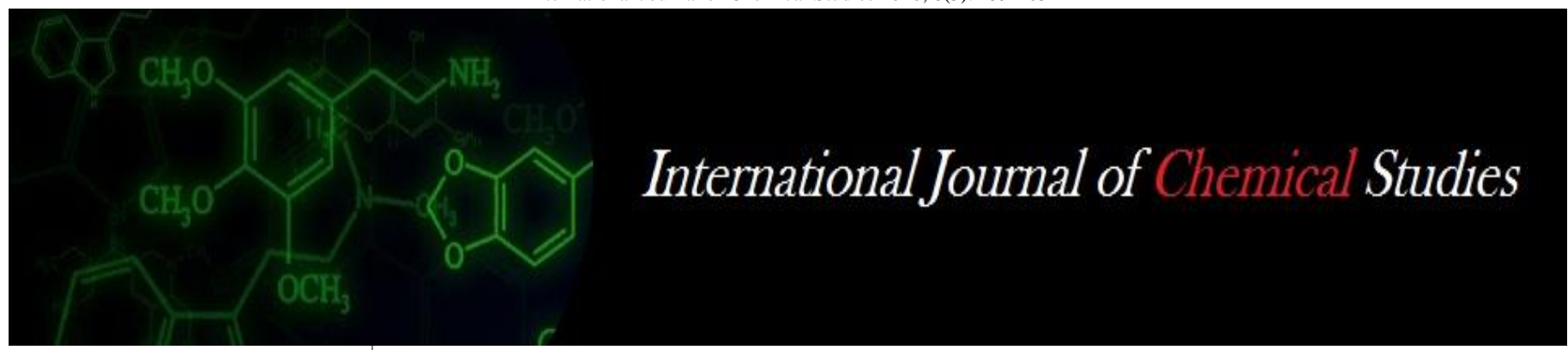

P-ISSN: 2349-8528

E-ISSN: 2321-4902

www.chemijournal.com

IJCS 2020; 8(3): 159-163

(C) 2020 IJCS

Received: 28-03-2020

Accepted: 30-04-2020

Subarna Ghosh

Post Graduate Student, College

of Agricultural Engineering,

Bapatla, Guntur District,

Andhra Pradesh, India

Venkata SP Bitra

Professor and Head (FPT)

College of Agricultural

Engineering, Bapatla, Guntur

District, Andhra Pradesh, India

\section{Phorbol ester degradation using chemical treatment in jatropha kernel meal}

\author{
Subarna Ghosh and Venkata SP Bitra
}

DOI: https://doi.org/10.22271/chemi.2020.v8.i3b.9219

\begin{abstract}
Detoxification of jatropha (Jatropha curcas) kernel meal is of major interest for the biodiesel industry to add economic value to this residue and also to reduce the environmental damage caused by its inappropriate disposal. Anti-nutritional factors present in jatropha kernel meal are phorbol esters, lectins, trypsin inhibitor, phytate and saponins. Toxicity of meal is mainly due to the presence of phorbol esters. Several methods have been tried for detoxifying kernel meal that includes physical, chemical, biological and radiation methods.

In the study, four different samples, i.e., raw, defatted, one-time mechanically oil expressed and twotimes mechanically oil expressed samples were prepared from jatropha kernels. These samples were subjected to chemical treatment for phorbol ester degradation. Chemical treatment involved heating the samples with $90 \%$ methanol and $4 \% \mathrm{NaOH}$ twice. Phorbol ester content was estimated using standard analytical procedure before and after the treatment. In chemically treated kernel meal, phorbol esters were found to be in range of $0.034-0.052 \mathrm{mg} / \mathrm{g}$.
\end{abstract}

Keywords: Detoxification, oil expressed kernel meal

\section{Introduction}

Jatropha is an oilseed crop belonging to Euphorbiaceae family which has gained remarkable interest as a raw material for biodiesel industries. Jatropha seed contains approximately 30$35 \%$ oil that can be converted into high-quality biodiesel upon trans-esterification which can be used as a substitute for diesel fuel ${ }^{[1]}$. Presence of various anti-nutritional factors in the jatropha kernel meal (prepared using mechanical oil expellers) prevents its use as highly nutritious protein supplement in animal feed. The anti-nutritional factors are phorbol esters, lectin, trypsin inhibitor, phytate and saponins (Table 1) ${ }^{[2,3]}$.

Table 1: Anti-nutritional components in jatropha kernel meal

\begin{tabular}{|c|c|c|c|}
\hline \multirow{2}{*}{$\begin{array}{c}\text { Toxic and Anti- } \\
\text { Nutritional Compound }\end{array}$} & \multicolumn{3}{|c|}{ Seed Variety } \\
\cline { 2 - 4 } & $\begin{array}{c}\text { Cape Verde } \\
\text { (Highly Toxic) }\end{array}$ & $\begin{array}{c}\text { Nicaragua } \\
\text { (Highly Toxic) }\end{array}$ & $\begin{array}{c}\text { Mexican } \\
\text { (Non-Toxic) }\end{array}$ \\
\hline Phorbol ester (mg/g kernel) & 2.70 & 2.17 & 0.11 \\
\hline Lectin (mg/g kernel) & 102.00 & 102.00 & 51.00 \\
\hline Trypsin inhibitor activity (mg inhibition/ g kernel meal) & 21.30 & 21.10 & 26.50 \\
\hline Phytate (\% in kernel meal) & 9.40 & 10.10 & 8.90 \\
\hline Saponin (\% diosgenin eqv. in kernel meal) & 2.60 & 2.00 & 3.40 \\
\hline
\end{tabular}

Jatropha kernel meal contains lignocelluloses and proteins in abundance and thus can be used advantageously as bio-fertilizer ${ }^{[2]}$ for production of biogas and as well as animal feed ${ }^{[4]}$. But, toxic phorbol esters that are naturally-occurring compounds are also present. Phorbol esters are widely distributed in plant species in the families of Euphorbiaceae and Thymelaeceae. They are tetracyclic diterpenoids of phorbol type and esters of tigliane diterpenes. Animal consumption of these phorbol esters can cause diarrhoea, inflammation of the gastrointestinal tract and death. If jatropha kernel meal is detoxified, it could be an excellent protein source. Several methods have been tried for detoxifying kernel meal that includes physical, chemical and biological methods ${ }^{[5]}$.
Corresponding Author: Subarna Ghosh

Post Graduate Student, College of Agricultural Engineering,

Bapatla, Guntur District,

Andhra Pradesh, India 
Physical and chemical methods for the detoxification of jatropha seed cake involve heat treatment that employs the use of moist heat. Moist heat along with other treatments results in a partial decrease in phorbol ester content. Because of the polar nature of phorbol esters, organic solvents like methanol and ethanol can be used for detoxification of seed cake; but, treatment with methanol makes the process nonecofriendly because of its toxic nature ${ }^{[6,7]}$.

According to earlier studies, phorbol ester content can be decreased by either ethanol extraction or sodium hydrogen carbonate treatment or a combination of both. However, phorbol esters are still present in a detectable level that is too high for producing feed for farm animals and aquaculture species.

This study was carried out to find the effects of chemical treatment on phorbol ester degradation in jatropha kernel meal. This kind of research is of great importance so as to incorporate jatropha kernel meal in commercially produced aqua-feeds after evaluating the toxicity levels of treated jatropha kernel meal. Keeping in view, the present work was conducted with the following specific objectives:

1. To study the effect of chemical treatment on phorbol ester degradation in jatropha kernel meal
2. To estimate phorbol ester content in the kernel meal after treatment

\section{Materials and Methods}

Jatropha seeds were obtained from Samarlakota, East Godavari District, Andhra Pradesh. Seed coat was removed mechanically using castor sheller adjusted suitably to obtain kernels. Four different jatropha kernel meal samples were prepared, namely, a) raw, b) defatted (solvent extracted), c) one-time mechanically oil expressed and d) two-times mechanically oil expressed. Jatropha kernels were size reduced in Wiley mill (Ultra Lab Instruments, New Delhi) using 20 mesh screen $(850 \mu \mathrm{m})$ for preparing raw sample. This 20 mesh raw sample was oil extracted with automatic Soxhlet apparatus using petroleum ether (boiling point: $65^{\circ} \mathrm{C}$ ) as solvent to produce defatted sample. Mechanical oil expression of jatropha kernels was done using mechanical mini oil expeller (Rajkumar Agro Engineers Pvt. Ltd., Nagpur) to obtain one-time mechanically oil expressed sample and two-times mechanically oil expressed sample. It is to be noted that the defatted sample was without oil in it. All the prepared samples were stored at $4{ }^{\circ} \mathrm{C}$ in a refrigerator till treatment was carried out (Fig. 1).

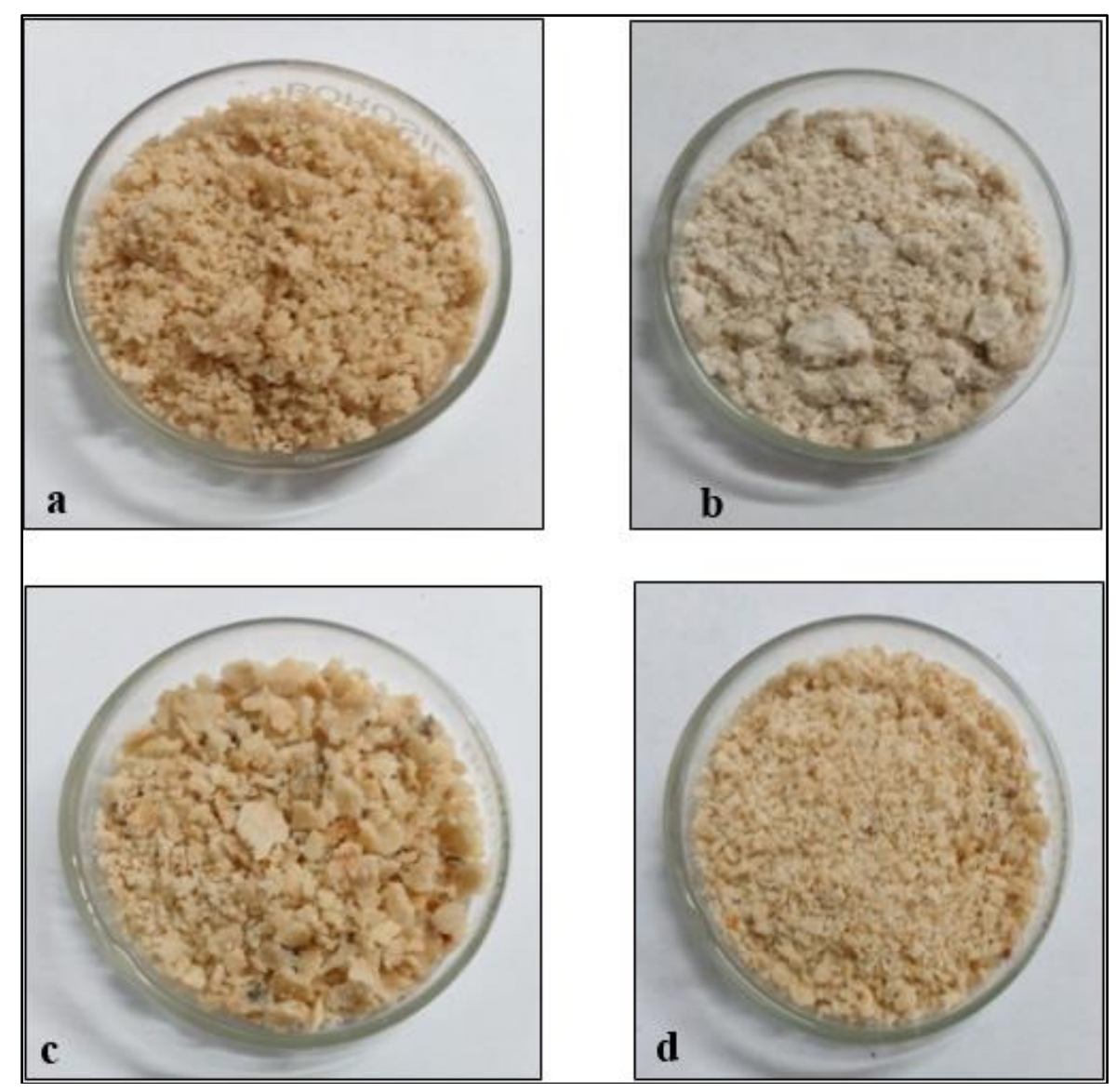

Fig 1: Jatropha kernel meal samples before treatment a) Raw, b) Defatted, c) One-time mechanically oil expressed and d) Two-times mechanically oil expressed

\section{Chemical Treatment}

Chemical treatment of the samples was done in two steps as mentioned in US patent application by Makkar and Becker (2011) ${ }^{[8]}$. It was reported that washing with methanol along with alkali $(\mathrm{NaOH})$ was more effective in reduction of toxins (especially, phorbol esters) than ethanol.

In the first step, 90\% methanol (methanol:water $=9: 1$ ) containing $\mathrm{NaOH}$ at a concentration of $0.1 \mathrm{M}(0.4 \mathrm{~mL}$ of 0.1 $\mathrm{M} \mathrm{NaOH}$ in $99.6 \mathrm{~mL}$ of $90 \%$ methanol) was added to kernel meal in the ratio $10: 1(\mathrm{v} / \mathrm{w})$ to obtain a mixture. The mixture was heated for $30 \mathrm{~min}$ in a refluxing unit; temperature of the mixture being $70{ }^{\circ} \mathrm{C}$. After heating for $30 \mathrm{~min}$, the mixture was transferred to a Buchner funnel, filtered to obtain the residue and the filtrate was discarded. The obtained residue was washed with $90 \%$ methanol (volume of this solvent was 1.2 times the weight of the kernel meal initially taken) and the washed residue was collected. 
In the second step, which is similar to first step, the washed residue from first step was transferred into another container, $90 \%$ methanol was added in the ratio of 10:1 (v/w) to obtain a mixture that was heated for $30 \mathrm{~min}$ while the solvent was being refluxed. The mixture was filtered and washed with 90\% methanol as stated above in first step, and the residue was dried at room temperature by spreading. Chemically treated samples are shown in Fig. 2.

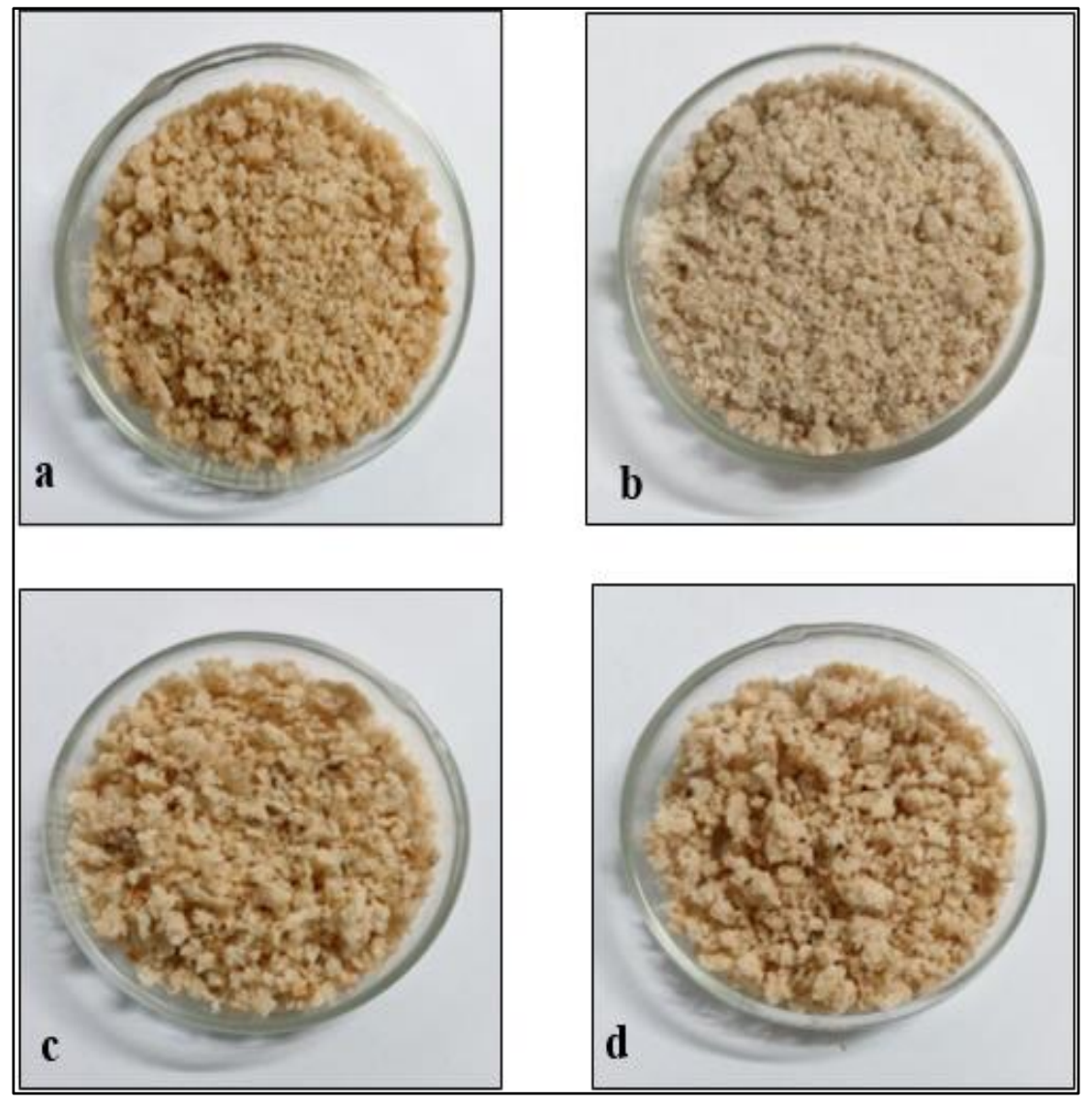

Fig 2: Chemically treated jatropha kernel meal samples a) Raw, b) Defatted, c) One-time mechanically oil expressed and d) Two-times mechanically oil expressed

\section{Estimation of Phorbol Esters}

Phorbol esters were determined according to the modified method of Haas and Mittelbach (2000) ${ }^{[9]}$ proposed by Saetae and Suntornsuk (2010) ${ }^{[10]}$.

Jatropha curcas kernel meal samples ( $5 \mathrm{~g}$ ) were ground by using a blender and poured into flasks containing $20 \mathrm{~mL}$ of methanol. Mixture of kernel meal and methanol was stirred by using a shaker operated at $250 \mathrm{rpm}$ for $5 \mathrm{~min}$. It was then filtered using a Whatman No. 4 filter paper and vacuum pump. Residue on the filter paper and the extract were collected. This process was repeated and the residue was extracted four additional times. The extract fractions from all five extractions were combined and dried under vacuum at 40 ${ }^{\circ} \mathrm{C}$ using a vacuum oven. The dried extract was dissolved in 5 $\mathrm{mL}$ of methanol and passed through a $0.2-\mu \mathrm{m}$ membrane filter (ChroMex, U.K.). Exactly $20 \mu \mathrm{L}$ of extract solution was analyzed for phorbol esters by HPLC (Model 1100; Agilent, USA).

HPLC analytical column used was a $150 \times 3.9 \mathrm{~mm}$ ID, $4-\mu \mathrm{m}$ particle size, Nova-Pak C18 (Waters, Ireland), with a SBC18 guard column $(12.5 \times 4.6 \mathrm{~mm}$ ID), $5-\mu \mathrm{m}$ particle size (Agilent, USA). The column was thermally controlled at $25^{\circ} \mathrm{C}$. A mixture of acetonitrile (HPLC grade; Fisher Scientific, U.K.) and deionized water in the ratio of 80:20 (v:v) was used as the mobile phase at a flow rate of $1 \mathrm{~mL} / \mathrm{min}$. The detector wavelength was set at $254 \mathrm{~nm}$. Results were expressed as equivalent to phorbol-12-myristate-13-acetate (PMA) (Sigma, U.K.) used as an external standard. The PMA was dissolved in methanol (Fisher Scientific, U.K.) for preparation of standard curve.

\section{Statistical Analysis}

Statistical analysis was carried out using one-way ANOVA in Microsoft Excel. Statistical significance of phorbol ester content in raw, defatted, one-time and two-times mechanically oil expressed samples before and after treatment was analyzed at $\mathrm{p}<0.05$.

\section{Results and Discussion \\ Phorbol esters content before treatment}

Phorbol ester content was analyzed for raw, defatted, onetime and two-times mechanically oil expressed kernel meal before treatment. The phorbol ester content was $0.901 \mathrm{mg} / \mathrm{g}$ of kernel meal for raw sample, whereas it reduced to 0.250 $\mathrm{mg} / \mathrm{g}$ of kernel meal for defatted sample (Fig. 3). One-time and two-times mechanically oil expressed samples showed phorbol ester content of 0.458 and $0.350 \mathrm{mg} / \mathrm{g}$ of kernel meal. Phorbol esters reduced in mechanically expressed and defatted samples because of extraction of oil. During mechanical extraction of oil from seeds, $70-75 \%$ of PE comes out with oil, but the rest are still retained in the kernel meal, thus making both the meal and oil inedible [11]. Thus, with decrease in oil content PE content also decreased (Fig. 4). Statistical analysis by ANOVA showed no significant difference in PE content $(\mathrm{p}<0.05)$. 


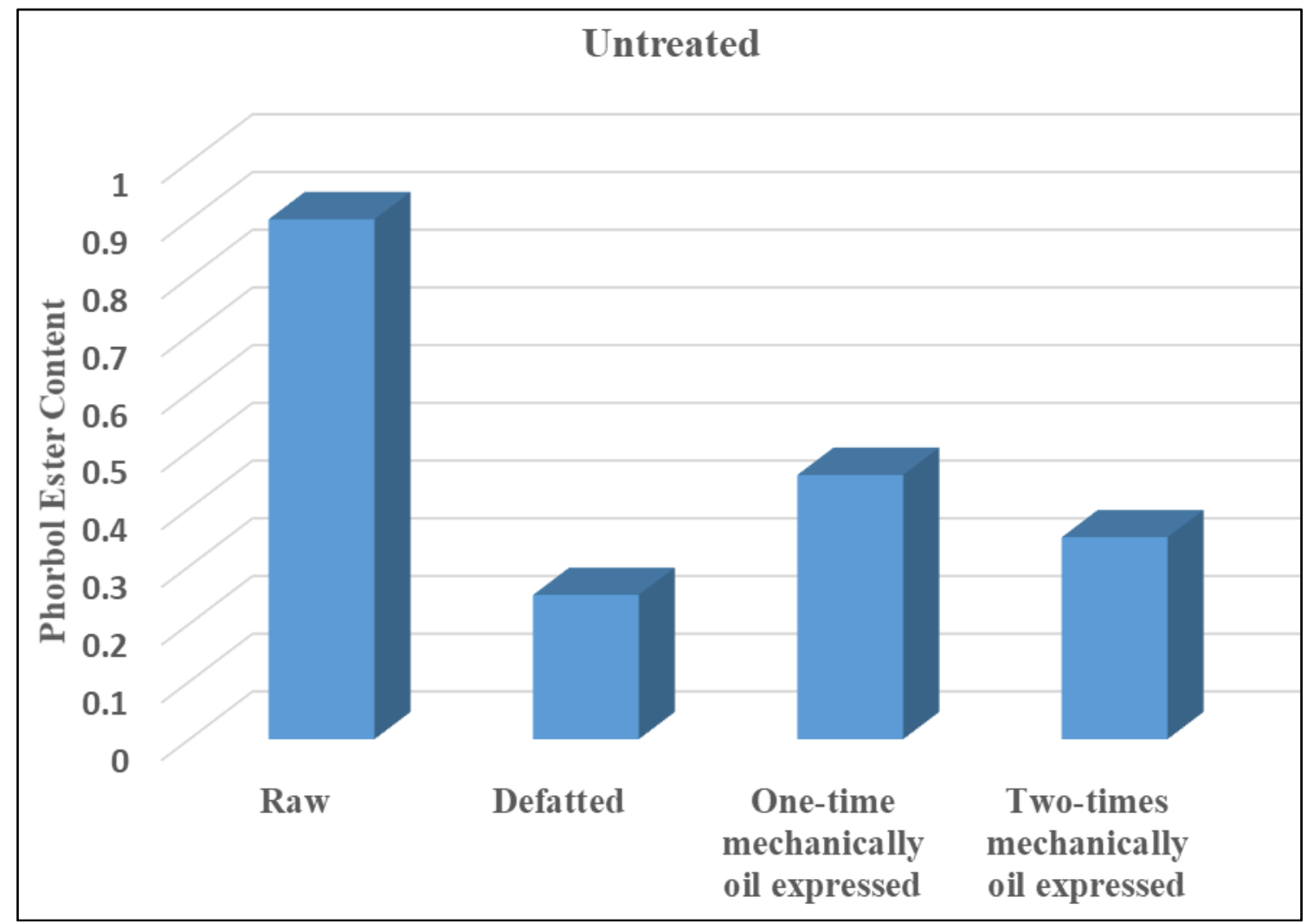

Fig 3: Phorbol ester content before chemical treatment

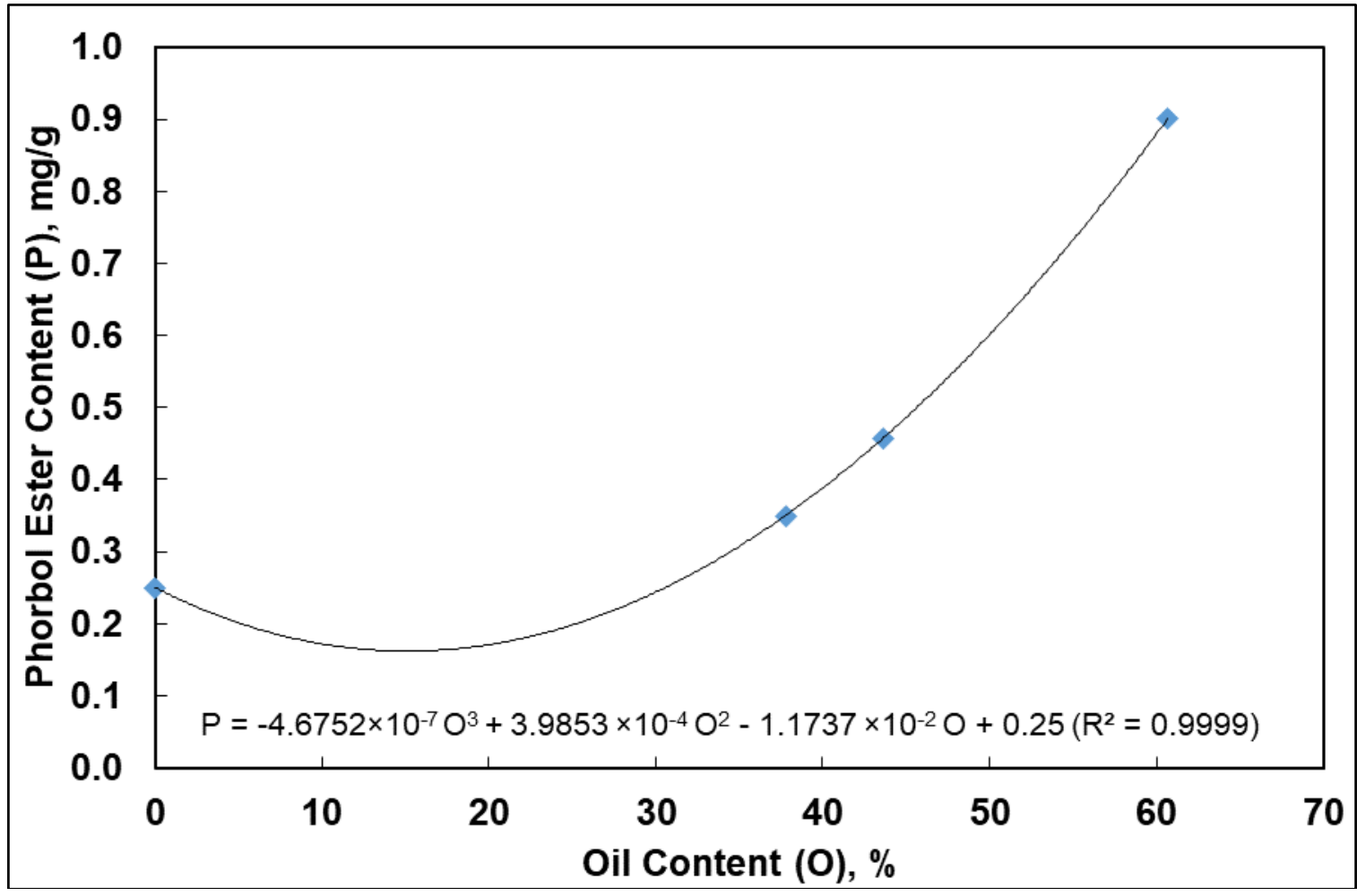

Fig 4: Variation of phorbol ester content with oil content Phorbol ester content after chemical treatment

Phorbol ester (PE) content was analyzed after chemical treatment of raw, defatted, one-time and two-times mechanically oil expressed kernel meal and the results are expressed in $\mathrm{mg} / \mathrm{g}$ of kernel meal (Fig. 5). PE content of chemically treated samples is less than the untreated samples. The PE content in raw and defatted sample was observed to be 0.037 and $0.034 \mathrm{mg} / \mathrm{g}$ of kernel meal, respectively. Onetime and two-times mechanically oil expressed samples showed PE content of 0.048 and $0.052 \mathrm{mg} / \mathrm{g}$ of kernel meal, respectively. The PE content decreased significantly/drastically to lower levels $(p<0.05)$ for all the chemically treated samples compared to untreated samples (Fig. 3). Phorbol ester reduced by $95.89 \%, 86.40 \%, 89.52 \%$ and $85.14 \%$ compared to untreated samples, respectively (Table 2). PE content in all the cases is within the acceptable limit of $0.11 \mathrm{mg} / \mathrm{g}^{[3]}$. 


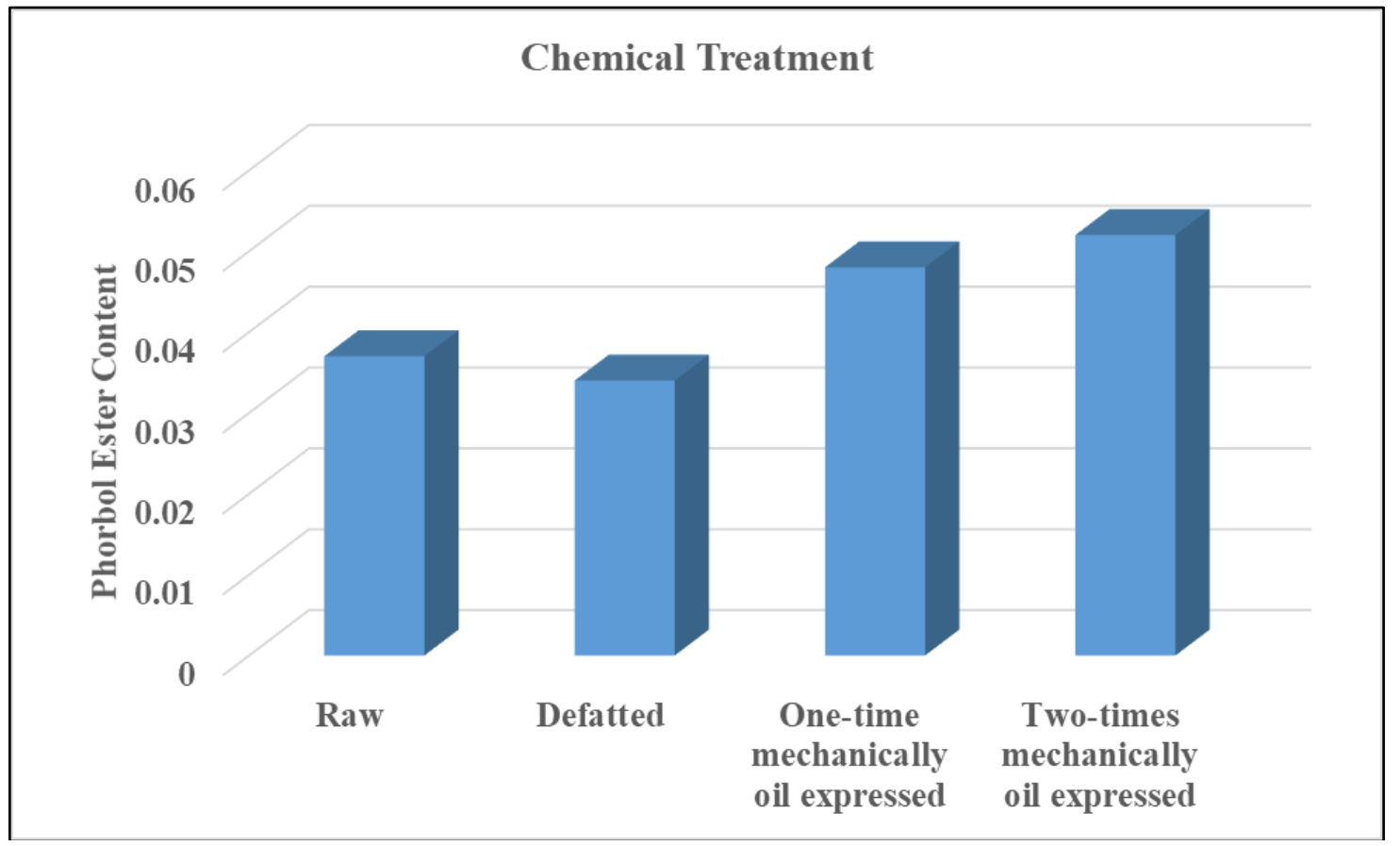

Fig 5: Phorbol ester content after chemical treatment

Table 2: Per cent reduction in phorbol esters due to chemical treatment over untreated samples

\begin{tabular}{|c|c|}
\hline Sample & Per cent Reduction \\
\hline Raw & 95.89 \\
\hline Defatted & 86.40 \\
\hline One-time mechanically oil expressed & 89.52 \\
\hline Two-times mechanically oil expressed & 85.14 \\
\hline
\end{tabular}

\section{Conclusion}

Study on phorbol ester degradation using chemical treatment in jatropha kernel meal was done to find the effectiveness of the treatment to detoxify jatropha kernel meal. Toxin content was also determined to ensure its suitability in food or feed purposes. Chemical treatment was carried out using $90 \%$ methanol with $4 \% \mathrm{NaOH}(0.1 \mathrm{M})$. Phorbol ester content was found to be high in untreated samples and was not within acceptable limits. Chemical treatment was found to be effective in reduction of phorbol esters. Chemically treated kernel meal showed lower phorbol ester content with 0.037 $\mathrm{mg} / \mathrm{g}$ for raw sample, $0.034 \mathrm{mg} / \mathrm{g}$ for defatted sample, 0.048 $\mathrm{mg} / \mathrm{g}$ for one-time mechanically oil expressed sample and $0.052 \mathrm{mg} / \mathrm{g}$ for two-times mechanically oil expressed samples and the corresponding per cent reduction was $95.89 \%$, $86.40 \%, 89.52 \%$ and $89.14 \%$, respectively.

\section{References}

1. Makkar HPS, Becker K. Jatropha curcas, a promising crop for the generation of biodiesel and value-added coproducts. European Journal of Lipid Science and Technology. 2009; 111:773-787.

2. Makkar HPS, Aderibigbe AO, Becker K. Comparative evaluation of non-toxic and toxic varieties of Jatropha curcas for chemical composition, digestibility, protein degradability and toxic factors. Food Chemistry. 1998; 62(2):207-215.

3. Makkar HPS, Becker K. Potential of J. curcas seed meal as a protein supplement to livestock feed, constraints to its utilisation and possible strategies to overcome constraints. In: Gubitz GM, Mittelbach M Trabi M.
(Eds.) Biofuels and Industrial Products from Jatropha curcas. Dubrovnik, Graz. 1997, 190-205.

4. Gubitz GM, Mittelbach M, Trabi M. Exploitation of the tropical oil seed plant Jatropha curcas L. Bioresource Technology 1998; 67:73-82.

5. Ahluwalia S, Bidlan R, Sharma JG, Singh P. Review on phorbol ester degradation of jatropha seed cake for its use as animal feed. International Journal of Pharmacy and Pharmaceutical Sciences. 2017; 9(1):7-13.

6. Makkar HPS, Becker K, Sporer F, Wink M. Studies on nutritive potential and toxic constituents of different provenances of Jatropha curcas. Journal of Agricultural and Food Chemistry 1997; 45:3152-3157.

7. Chivandi E, Erlwanger KH, Makuza SM, Read JS, Mtimuni JP. Effects of dietary Jatropha curcas meal on per cent packed cell volume, serum glucose, cholesterol and triglyceride concentration and alpha-amylase activity of weaned fattening pigs. Research Journal of Animal and Veterinary Sciences 2006; 1:18-24.

8. Makkar HPS, Becker K. Detoxification of Jatropha curcas meal for feeding to farm animal species and fish. US Patent No. 2011/0311710 A1; 2011.

9. Haas W, Mittelbach M. Detoxification experiments with the seed oil from Jatropha curcas L. Industrial Crops and Products 2000; 12:111-118.

10. Saetae D, Suntornsuk W. Antifungal activities of ethanolic extract from Jatropha curcas seed cake. Journal of Microbiology and Biotechnology. 2010; 20(2):319324.

11. Devappa RK, Makkar HPS, Becker K. Localisation of anti-nutrients and qualitative identification of toxic components in Jatropha curcas seed. Journal of the Science of Food and Agriculture. 2012; 92:1519-1525. 